\title{
スペース・チェンバーと排気系*
}

\section{Vacuum Pumping System for Space Chambers}

中川洋**.角田竜啇**

Hiroshi Nakagawa and Ryuji Tsunoda

\section{1. まえがき}

宇宙開愽の進展にともなって，実際に衛星を打ち上 げたり，それによって各種のデータを追跡するプロ ジェクトの開発とともに，打ち上げ時や飛行時の状態 を地上でシュミレートしたり，各部品を宇宙環境下で テストする必要が増大してきた. てのようなシミュミ レーションはその目的によって多くのシミュレートの 方式とそれに用いる数多くの機器を必要とするが, そ れらのなかで，最あ一般的であり，また最すよく使わ れているのは,いわゆるスペース・チェンバーである.

宇宙開発の先進国であるアメリカではすでに 1,000 基以上ものスペース・チェンバーが設置されたと称せ られており，宇宙開発予算の削減に伴ってそのうちの 相当なあのは遊休中であるとさえいわ机るまでに普及 している. また，その性能む基本的なすのはほとんど 開発しつくされたと見てよく，現在は月面上の状態を シミュレートするチェンバーとか，より宇宙環境に近 い状態のシミュレートができるような高度の性能を 持ったチェンバーなど，特殊の技術を必要とするすの が研究されている.

わが国では，現在のところ，大小合わせて十数基の スペース・チェンバーまたはその類似の試験装置が作 られたにすぎず，シミュレート方式の研究や装置の運 転方法，さらに設計製作技術の面であ未だ研究を要す る点が多く残されていると考えられる. 今後，わが国 の宇宙開発プロシェクトをさらに進展させるために あ，より信頼性の高いシミュレーション技術やスペー ス・チェンバーを開発して行く必要がある.アメリカ のみならず， ヨーロッパ各国特にドイッ，フランスは この方面に相当の力を注いでいるように見受られるの で，せめてヨーロッパなみの技術水準は確保しておか ねばならないと考えられ，そのためにもわが国独自の 技術やアイデアの盛られたとの種施設の急速な整備が 望まれる。

このような目的のために解決すべき問題点は数多く あるが, 本稿では, スペース・チェンバーに関する技

* 昭和 45 年 4 月 28 日原稿受理

** 日本酸素(株)技術研究所
術的問題点，とくに基本条件の一つである玨力環境の シミュレーション，すなわち高真空に排気し，それを 維持し計測するという技術についてその概要を述べた いと思う. むちろん，スペース・シミュレーションの 問題点はこのような区力の問題のほかに, 低温環境, ソーラー・シミュレーション，データ观理など数多く の重要な点があるが，てれらについては別に解説され るであろう。

2. スペース・チェンパーとその圧力・排気系

宇宙空間における圧力は，その定義の下し方や，条 件によって異るが, 一般的には第 1 図に示すように。 地球加らの高度之対数的な関係にある ${ }^{11}$. 普通の人工 衛星が飛行する軌道上ではほほ $10^{-6} \sim 10^{-11}$ Torr の超 高真空の状態に近いといえる.しかし，このような圧 力の表し方は，高度数十 $\mathrm{km}$ 程度までは普通の希薄気 体の圧力の考え方でよいが，それ以上の高度において は，気体の分子はほとんどイオンとなっており，アポ 口計画でも太陽風の測定という表現が使われたように 非常に高速のイオン流の状態となっている，このよう な空間では，いわゆる圧力の考え方でなくイオンの 数，すなわち密度を測定し便宜的に通常の圧力に換算 したものが使われるので，地上でわれわれが作りだす 真空状態とは加なり状況が違っている，したがって， スペース・チェンバーを単に高真空に排気しただけ で，宇宙空間のシミニレートできるといえるかどうか が大きな問題である.しかす，上記のようなイオン流 の状態を実圐することは，実際上は非常に難かしいの

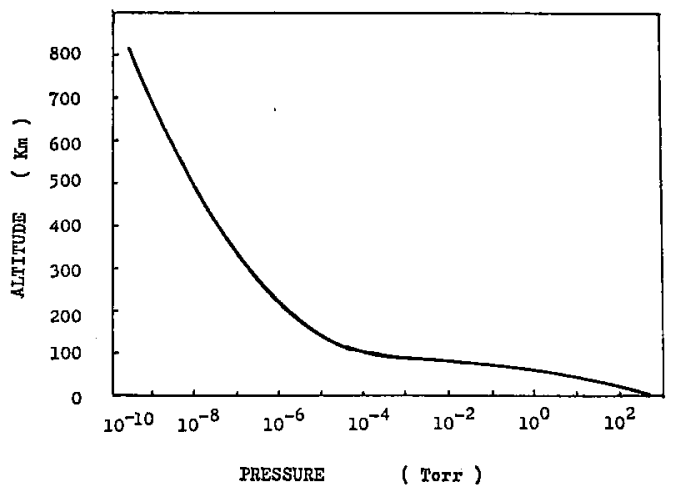

第 1 図高度之圧力の関係 
て，どの辺で妥協するかむ問題の一つである.

このような，超高真空に相当する王力を実現せねば ならないシミュレーション試験のほかに, 地上に近 い, 比校的高度の低い空間のシミュレーションも重要 な分野である.

ここではまず，スペース・チェンバーの使用圧力 と，それに必要な排気系を基にして，分類してみる.

2.1 低圧環境試験 との試験は, 地上加らロケッ 卜が打ち上げられて，人工衛星が軦道にのるまでの範 园に括ける压力のシミュレーションであり，圧力が大 気圧加ら $10^{-3}$ Torr 程度まで急速に下がることによる 各構成部分や人工衛星自体への影響，衝整，振動など の試験，さらにロケット・エンジンの低圧下における 動作試験，希薄気体風洞の実験などを含んでいる，こ れらのシミュレーションに用いるチェンバーの圧力は 大気訨から $10^{-3}$ Torr 程度までで，あまり高真空を必 要としないが，一方大気圧付近加急速に非気するた めに取报うガスの量が非常に多くなり，また，ロケッ トの動作試験などは発生ガスを一気に排気する必要加 ら取り报うガス量も膨大なむのとなるのが普通であ 万.

これらの試験のうち，とくに压力の面，すなわち非 気特性から見て興味樑いものとしてロケット打ち上げ 後の圧力変化のシミュレーションがある.との試験は 人工衛星本体および衛星搭載計器類の急激な圧力变化 による影響をシミュレートするもので，大気压加ら $10^{-3}$ Torr 程度まで, 口ケット上昇による圧力変化に 合わせて，チェンバーを排気する必要がある.

DOWLING ${ }^{22}$ は第 2 図に示すような排気系で急速排気 を行なった，通常は10Torr 以下で作動するように設 計された真空用の大型ルーツ型ブロワを 3 段シリーズ に配置し，大気压加ら同時に始動させた. スタートし てからある圧力に下がるまでは空気は各ポンプの吐出 側加ら直接大気に放出され，吸入側の正力が下るに 伴って，次第にシリーズ運枟に入るよう計画されてい る.

中山らろ゙ての排気方法こ同様な考え方を発展さ せ，10 $\mathrm{m}^{3}$ のチェンバーを $1 \times 10^{-2}$ Torr まで 50 秒で

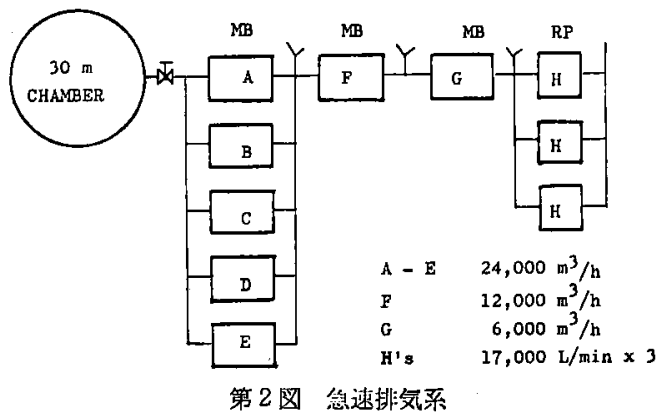

排気した，との50 秒はわが国の固体燃料を用いた口 ケットの上算速度から決好られた時間であって，液体 燃料它用いたロケットの上昇速度よりは，はるかに早 い圧力減少時間である. との排気系は, $5,000 \mathrm{~m}^{3} / \mathrm{h}$ お よび $2,500 \mathrm{~m}^{3} / \mathrm{h}$ 各 2 基のルーツ型ポンプをシリーズ に配置し，さらに第 3 段として 15,000 l/min のロータ リー・ポンプと $2 \mathrm{~m}^{3}$ の真架タンクを付属させている. さらに，乙の排気系はプログラム制御による排気速度 の調整機構が組み込まれていて，前記 50 秒を適当な 時間延長したり，ある圧力からある圧力に下がる時間 を調節することができる，第 3 図にこの排気系で得ら れた真空排気曲楾を示す.

CooK ら は) は土衛星の急速排気試験を行ない, チェンバーの圧力および衛星内部の圧力を測定し第 4 図に示すように圧力の偏在のあるととを報告してい る、との点は圧力変化のシミュレーションが, 衛星内 部が目的の場合は大きな問題となることを示唆してい る.
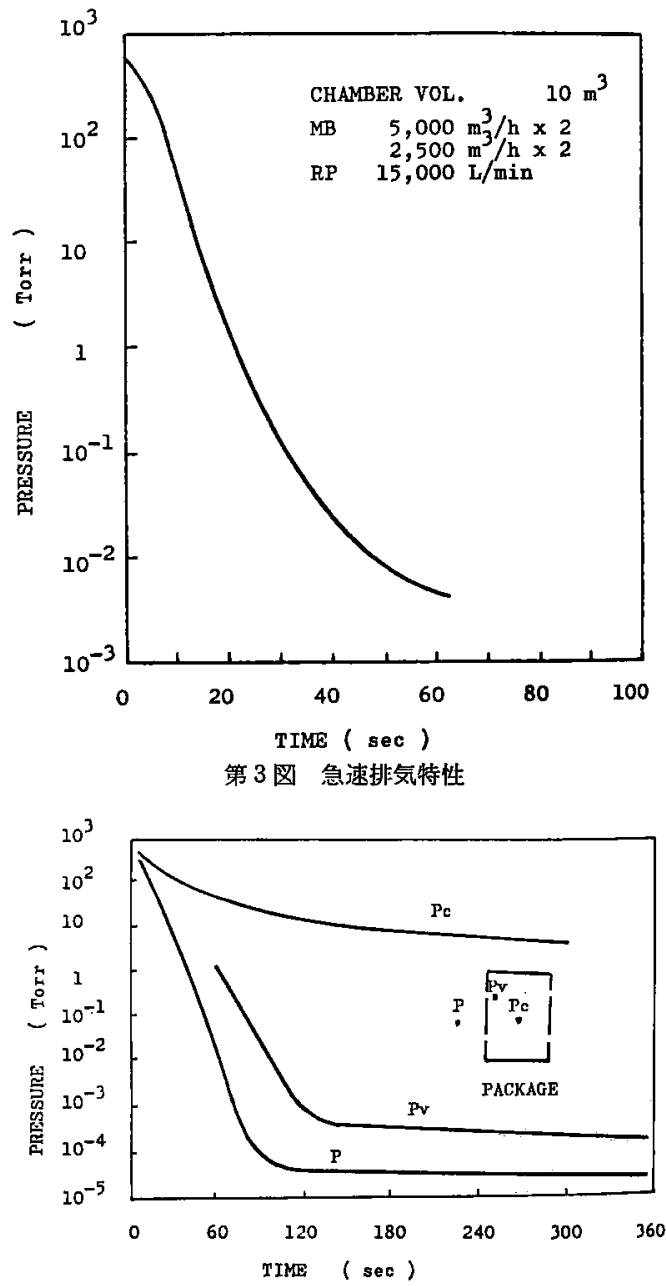

第 4 图 急速排気におけるチェンバー内の圧力分布 
この程度の正力の下で，ロケットを実際に燃佬させ て，低圧下の燃焼状況，推力の測定などを目的とした チェンバーああるが，この種のチェンバーに付属する 排気系が非常に大きな排気能力を必要とし，通常の排 気系では，真空を維持することはむずかしい，このよ うな場合の例は次節で述べる.

2.2 高真空環境試験 この試験は $10^{-3}$ Torr 程度 から $10^{-8}$ Torr 程度までの圧力笘围で行なわれるすの で，具体的には熱真空環境試験，イオン・エンジン， 姿勢制御口ケット試験, 部品材料の高真空下の試験な どが含まれている. 現在作られているスペース・チェ ンバーの大部分はこの籁囲の圧力で使われている.

熱真空環境試験は人工衛星の温度バランス，材料部 品の作動状態などをシミュレートするものであって, 最す雷要な試験の一つである.この環境条件は正力の $10^{-3} \sim 10^{-8}$ Torr のほかに, $100^{\circ} \mathrm{K}$ 以下の低温暗黒壁お よび照度 $1.4 \mathrm{~kW} / \mathrm{m}^{2}$ のソーラー照射などである. こ れについては後に詳しく述べたい。

人工衛星の姿勢制卸に用いられる炭酸ガスやへリウ 么噴出口ケットおよひ宇宙航行に使われるイオン・エ ソジンなどの大量のガスを放出する一方，チェンバー 内を高真空に保持する必要がある場合の排気系はその 構成は非常にむずかしく，一例として第 5 図に示した ような液体至素, 液体水素, 液体へリウムの冷却面を チェンバー内にシリーズに配置した大がかりなクライ オ・ポンプによるものがある.とのようなロケット然 焼試験に用いるチェンバーの排気系は容量が大きいこ とが必要なだけでなく，燃焼ガスの組成による排気能 力を考慮せねばならない. 液体酸素, 液体水素の口 ケットならば発生ガスは主に水蒸気であるから，液体 窒素のクライオ・ポンプで十分であるが, 固体然料の 発生ガスは, 種々の非凝縮性ガス, 特に水烮, メタン なよ゙であるから，クライオ・ポンプで排気するにして

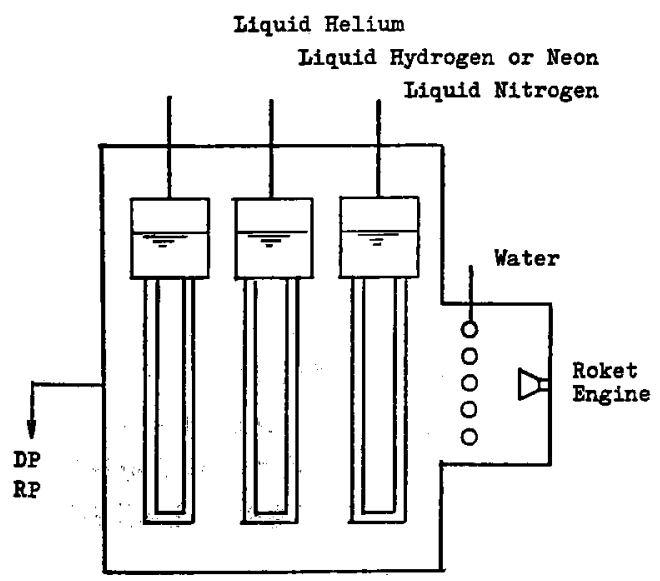

第 5 図 3 段クライオ・ポンプ
屯, 液体へリウム温度加必要になる. しか子発生ガス の量が高真空を維持するためにはあまりにも大量なの で, とのクライオ・ポンプの設計は非常にむずかし W.

2.3 超高真空環境試験 人工衛星が飛行する宇宙 空間に氺ける王力は一応 $10^{-8}$ Torr 以下の超高真空空 間であるとしてよい. したがって人工衛星のシミュ レーションは超高真空の空間で行なうのが理想的であ るが，大型のチェンバーを超高真空に排気することは 極めて困難であり，また可能であってる経済的な負担 が大きい，また万難を排して超高真空に排気したとし て屯，前述のように，てのような空間では気体分子は ほとんどイオン化しているととを考えると，いずれに しても完全なシミュレーションは困難である.した がって，多くのスペース・チェンバーでは必ずしも超 高真空を実現する必要はなく, 最少限に許容される誤 差範围の圧力条件でシミュレートが行なわれるのが普 通であり，熱バランスのシミュレーションは条件に

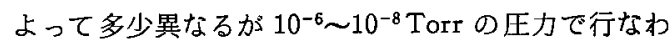
れる.しかし，とのような試験は後述のように圧力そ のものが問題というよりは，僅かに存在する気体分子 の与える影響の方が問題なのであって，正確には被試 験体に飛来する気体分子の密度, 頻度および被試験体 の表面との相互作用をシミュレートしなりればならな い. 高真空, 超高真空の下では，物質表面の物理，化 学的性状が，大気圧あるいは気体の環境下と全く異な り，たとえば物質の摩擦や摩耗の現象は $10^{-8}$ Torr 以 下では急激に摩擦係数が上昇することが知られてお り，人工衛星で機械的な運動をする部分は超高真空の 環境下で長時間の試験が必要となる。

Jet Propulsion Laboratory では, "Mariner Mars 1969 衛星” の部品を, モル・シンク・チェンバーで 超高真空環境下で 5 カ月間連続してテストを行なっ だ?. 特にカメラのシャッター部分, アンテナなど機 械的運動部分について，通常の高真空下での試験では 生じなかった現象が多く見出されている．完全に清浄 に保たれた金属面同志を摺動させると Cold welding とよばれる一柍の焼付が起こることは，宇宙空間にお けるこれら部品の譏械的動作を著しく困難にしてい て，このような目的のための不揮発性の潤滑剤などの 必要性は非常に央要であり，乙の開発のためにも超高 真空のスペース・チェンバー，あるいは，超高真空摩 擦摩耗試験器などが必要となってくる.

\section{3. スペース・チェンバーの真空的な問題}

使用圧力によってスペース・チェンバーの概要を説 明したが，本節ではその二，三についてより洋しく説 
明する.

3.1 オイル・フリー排気系 スペース・チェン バーにおける種々のシミュレート試験では, 生力の值 すなわち真空度よりも, 残留気体分子の密度, さらに その種類という考え方のほうが重要である.

初期のスペース・チェンバーは, 油拡散ポンプを主 体とした排気系が採用されていたが，油拡散ポンプか らチェンバーに逆流する油蒸気が被試験体の表面に付 着したり, 残留気体として存在するととが, 試験に重 大な悪影響を及伊すことを GILES ${ }^{5)}$ が明らかにしてか ら，オイル・フリーの排気系が望ましいという傾向に なってきた．現在では $10 \mathrm{~m}$ 以上の大型のチェンバー でも，多加少なかれオイル・フリーの排気系が採用 されるようになった．具体的な例とその性能について は後で述べる。

3.2 自己污染と排気系 宇宙空間では，人工衛星 から放出されたあるいは蒝発，昇華した分子は字宙空 間に飛去り，再び人工衛星に逆戻りすることはない。 しかしわれわれが実際にスペース・チェンバーでとの 状況をシミュレートするととは必ずしも容易ではな い. いくらチェンバーの内部が超高真空に保たれてい ても，被試験体から発生するガスは，たとえばチェンバ 一内壁には祖返されてモデルに戻る可能性が大きい，

CHUAN $^{6)}$ はこの点の考慮がシミュレーションに当 たって最あ重要であることをモデルの自己污染という 考え方で強調している. モデルから放出される分子数 上, 再びモデルに戻る分子数の此を自己污染係数 $C$ s と定義し，これは

$$
C_{s}=1 /\left\{1+\left(\frac{\eta_{c}}{1-\eta_{c}}\right)\left(\frac{A_{c}}{\eta_{m} A_{m}}\right)\right\}
$$

で表わされる. ここに $\eta_{c}, \eta_{m}$ はそれぞれチェンバー 内壁とモデル表面における分子の捕獲率（入射した分 子のうち，表面に止る分子の割合) であり， $A_{c}, A_{m}$ はそれぞれ，チェンバー内壁，モデル表面の表面積で ある。

シミュレーションの精度をよくするためには，自己 污染係数が小さいことが必要であり，そのためには (1)式加らわ加るように $\eta_{c}$ を大きく， $\eta_{m}$ を小さく， $A_{c}$ を大きく， $A_{m}$ を小さくすればよい， $\eta_{m}$ はモデル によって決まってくるので，結局は第 6 図に示すよう に， $\eta_{c}$ を大く，功 $A_{c} / A_{m}$ を大きくする必要があ る.

通常の真空装置のように，真空タンクの一部に排気 孔をあけて油拡散ポンプで排気するという方式では， モデルから放出された分子は，その大部分が，常温の チェンバー内壁で反射してしまうので さい值さなってしまう。したがって，クライオ・ポン

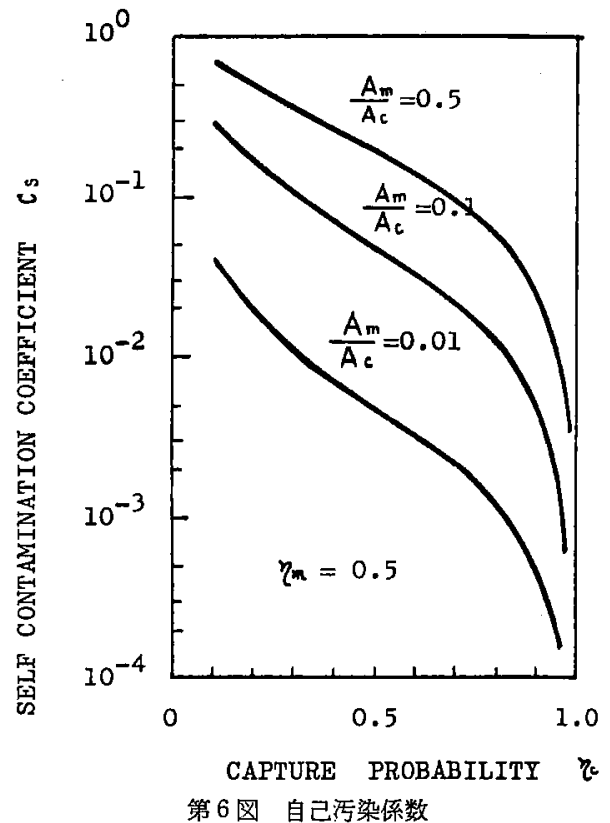

プのように，チェンバー内壁がポンプ作用のある冷却 面で包まれ，しかも大きいチェンバーに，小さなモデ

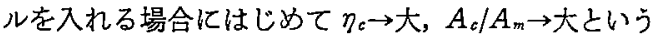
条件が満足される.

STEPHANS ${ }^{72}$ は第 7 图に示したモルシンクと称する 自己污染の非常に小さいチェンバーを開発し，前記の ように，今まで知られていなかったような種々の現象 を見出している．チェンバー内壁は $14^{\circ} \mathrm{K}$ のヘリウム クライオ・ポンプとなっているので $\eta_{c}=0.9$ 程度であ り，モデルは極めて小型として $A_{c} / A_{m}=100$ 程度に なっている. したがって $\eta_{m}=0.5$ としてす $C_{s}=10^{-3}$ の程度，すなわち $0.1 \%$ の程度のシミュレーションが 可能であるといっている.

3.3 温度相似係数と操作圧力 スペース・チェン バーの操作圧力は，その目的によって種々の場合があ るが，とんにち最す普通に使われている熱真空環境試 験について試験圧力, 到達圧力, 排気速度をどう決め るかについて論議する。

熱バランスのシミュレーションについては，実際の 人工衛星では，熱の収支は太陽輻射と搭載機器作動に よる熱入力之，宇宙空間への輻射による熱放出があ る.一方，地上のシミュレーションでは，このほかに 王力に依存する残留気体の熱伝導を考えねばならな い. どの程度の圧力にすれば，シミュレーションの精 度として十分であるかは熱移動について，分子熱伝覩 によるもの qa と, 楅射によるあの $q_{r}$ との比として

$$
S_{s}=\frac{q_{c}}{q_{r}}
$$




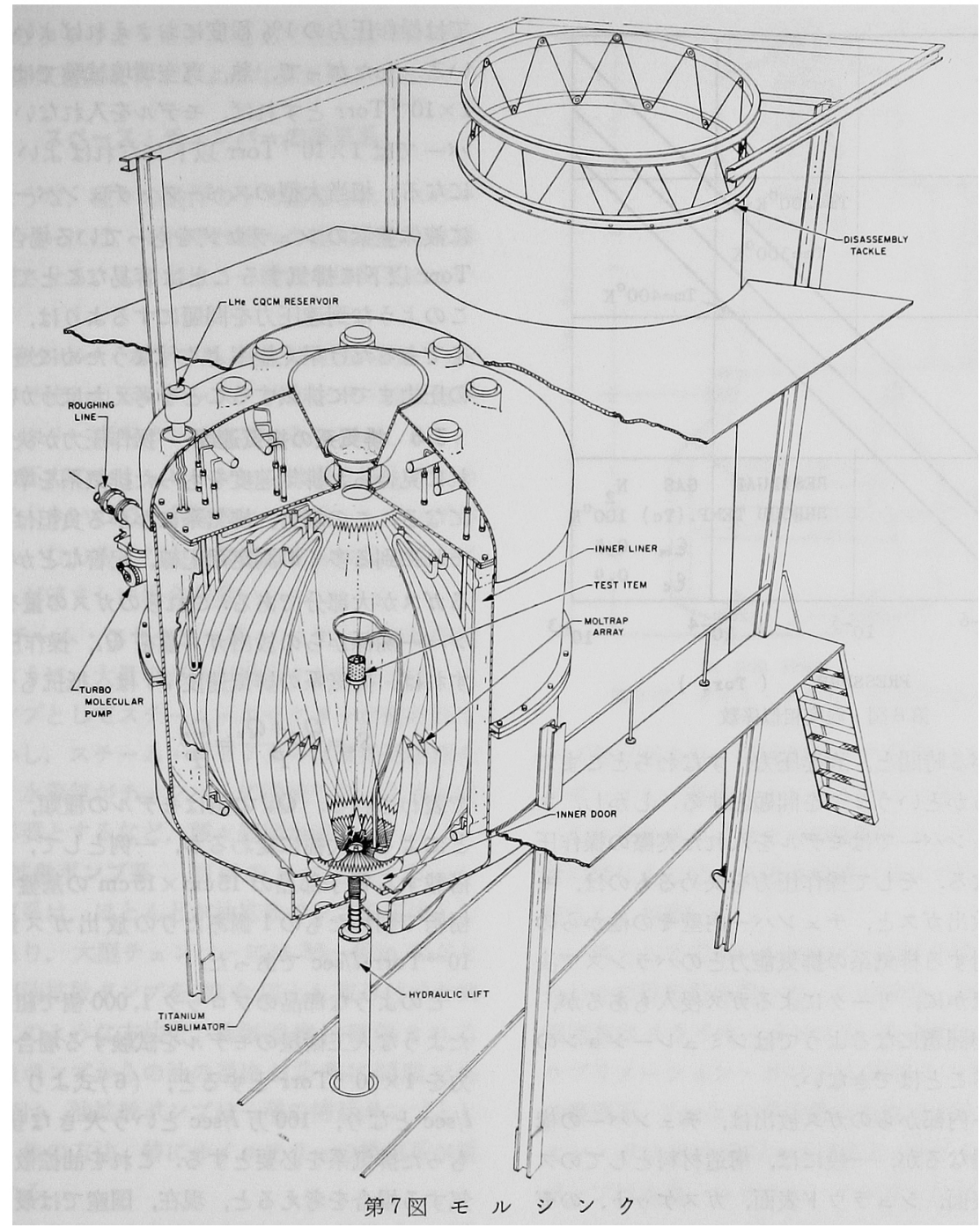

で定義される温度相似係数 $S_{\imath}$ によって決められる。 実際の宇宙空間では $q_{c} \fallingdotseq 0$ であるから，シミュレー ションの精度は $S_{t}$ が小さいほどよいことになる。

一方，分子熱伝導证気体分子運動論加

$$
\begin{aligned}
q_{c}= & \left\{\frac{1}{2}\left(\frac{\gamma+1}{\gamma-1}\right)\left(\frac{R}{2 \pi M T_{c}}\right)^{1 / 2}\right\} \\
& \times P_{c}\left(T_{m}-T_{c}\right) A_{m} \\
= & \Lambda_{c} P_{c}\left(T_{m}-T_{c}\right) A_{m}
\end{aligned}
$$

で表わされる.とてで $P_{c}$ はチェンバー内の圧力, $T_{m}$, $T$ はモデル，チェンバー内壁の温度， $A_{m}$ はモデルの 表面積， $\gamma$ は比熱比， $R$ はガス常数， $M$ は分子量で ある.

一方，輻射によるモデルとチェンバー内壁との熱移 動量は,

$$
q_{r}=\alpha\left\{\varepsilon_{m} A_{m} T_{m}{ }^{4}-\varepsilon_{c} A_{c}\left(\frac{A_{m}}{A_{c}}\right) T_{c}{ }^{4}\right\}
$$

で表わされる．とこに $\alpha$ は常数， $\varepsilon_{m}, \varepsilon_{c}$ はそれぞれモ デルとチェンバー内壁の湢射率， $T_{m} ， T_{c}$ はそれぞれ の温度， $A_{m}, A_{c}$ は表面積である. (2)，(3)，(4)式 加ら。

$$
S_{\iota}=\frac{\Lambda_{c} P_{c}\left(T_{m}-T_{c}\right)}{\alpha\left(\varepsilon_{m} T_{m}{ }^{4}-\varepsilon_{c} T_{c}{ }^{4}\right)}
$$

となり， $A_{m}, A_{c}$ とは無関係となる．との関係を図示 すると第 8 図のようになり， $S_{t}$ を $10^{-2}$ 。すなわ熱 シミュレーションの精度を $1 \%$ にする必要のある場合 には, モデルの温度 $I_{m}=300^{\circ} \mathrm{K}, \varepsilon_{m}=0.5, \varepsilon_{c}=0.9$ とすると $P_{c}=3 \times 10^{-5} \mathrm{Torr}$ となる．すなわち一般の 熱真㑨環境試験では，まず $1 \times 10^{-5}$ Torr 以下，すなお ち $10^{-6}$ Torr 台にチェンバー内の圧力を保てば十分で あることがわかる.

3.4 到達圧力 普通の真空装置では，その性能の 評価の基準として，排気時間，すなわち目的とする圧 


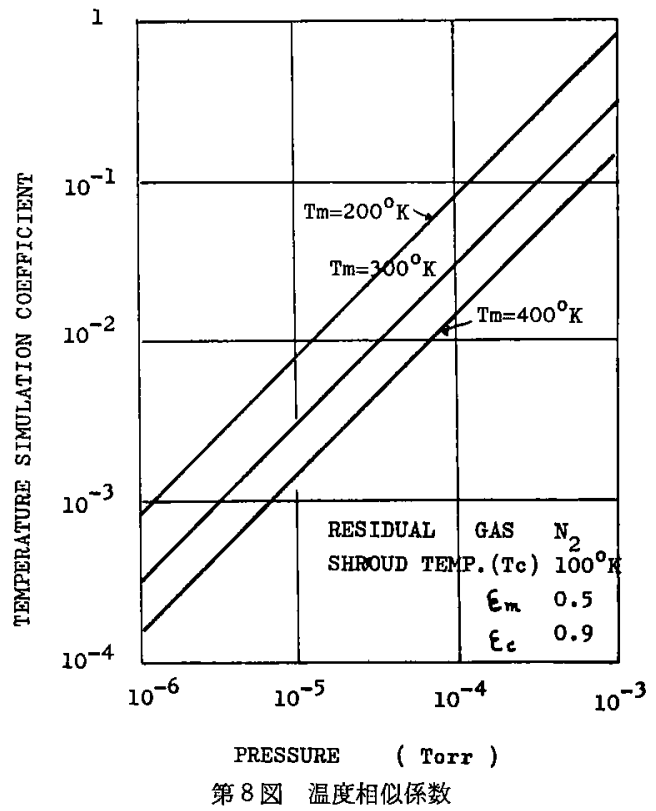

力にまで下がる時間と, 到達圧力, すなわちどこまで 圧力が下がるかという2つを問題上する. しかし， ス ペース・チェンバーではモデルを入れた実際の操作正 力が問題亡なる，そして操作圧力を決めるものは，モ デルからの放出ガスと，チェンバー内壁その他加らの 放出ガスに対する排気系の排気能力とのバランスで決 まる，とのほかに，リークによるガス侵入もあるが， 通常リークが問題になるようではシミュレーションの 目的を達することはでさない。

チェンバー内部加のガス放出は，チェンバーの構 造によって異なるが，一般には，構造材料としてのス テンレス鋼表面，シュラウド表面，ガスケット，のぞ き空のガラス，電力・機械動力導入端子などの表面か らのガス放出が考えられるが，シュラウドを冷却して いるときはそのうち $90 \%$ はステンレス鋼表面加らの 放出ガスである.

これらの放出ガスの量について，数多くの報告があ るが，研究者によって，また材料の経歴，処理方法な どによってあ大きな差がある，またべーク・アウトの 条件，すなわち温度，時間によってもその值は変わっ てくるが，筆者らが製作した中型のスペース・チェン バーについて見ると，まず $10^{-8}$ Torr 程度， $150^{\circ} \mathrm{C}$ で 十分ベークしたチェンバーを 30 分間大気にさらし， 排気を行なって 3 時間後で $1 \times 10^{-9}$ Torr $\cdot l / \mathrm{sec} \cdot \mathrm{cm}^{2}$, 5 時間後で $5 \times 10^{-10}$ Torr $\cdot l / \mathrm{sec} \cdot \mathrm{cm}^{2}$ であった。 ただ し，この計算は，放出ガスはすへて，チェンバー内壁 から出ているむのよして整理している.

スペース・チェンバーに机いては，到達圧力という 概念はあまり問題でないと述へたが，一応の基準とし
ては操作圧力の $1 \%$ 程度におさえればよいといわれて いる.したがって, 熱, 真空環境試験では, 操作压力 $1 \times 10^{-5}$ Torr とす狆ば，モデルを入机ない空のチェン バーでは $1 \times 10^{-7}$ Torr 以下になればよいというとよ になる．相当大型のスペース・チェンバーです, 内部 に液体窒素のシュラウドをもっている場合に $1 \times 10^{-7}$ Torr 以下に排気することは容易なことであるから， このような到達圧力を問題にするよりは，むしろ試験 をできるだけ早く能率よく行なうために短時間で目的 の圧力までに排気することを考えたほうがよい．

3.5 排気系の排気速度 操作圧力が決ま机ば，そ 扎に見合った排気速度をむった排気系を準備すること になる，乙の場合，排気系にかかる負担は，モデルや それに到る多くの测定用配線，配管などから放出され るガスが大部分である.これらのガスの量を $Q_{m}$, チェ ンバー関係からの放出ガス量を $Q_{c}$, 操作王力を $P$ と すれば，排気系の排気速度 $S_{e}$ は，抵抗も含めて，

$$
S_{e}=\frac{Q_{m}+Q_{c}}{P} \fallingdotseq \frac{Q_{m}}{P}
$$

で表わされる. $Q_{m}$ の值はモデルの種類，処理条件な どによって大幅に変わるが，一例として，人工衛星に 搭载する電子部品の $15 \mathrm{~cm} \times 15 \mathrm{~cm}$ の基盤をエポキシ 樹脂で固めたもの 1 個あたりの放出ガス量は $10^{-2}$ 〜 $10^{-3}$ Torr・l/sec であった.

とのような部品のブロック 1,000 個で組み立てられ たような人工衛星のモデルを試験する場合に，操作圧 力を $1 \times 10^{-5}$ Torr とすると，(6)式より $S_{e}=1 \times 10^{6}$

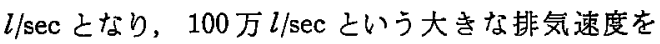
あった排気系を必要とする．とれを油拡散ポンプで非 気する場合を考えると, 現在, 国産では最大の排気速 度を有するものの一つと考える 46 in の油拡散ポンプ 1 台の排気速度は約 $10^{5} l / \mathrm{sec}$ であり, 配管やバッフル などの抵抗を考えれば，1台あたりの有効排気は $3 \times$ $10^{4} \mathrm{l} / \mathrm{sec}$ 程度となるから，この油拡散ポンプを 30 台 設置せ朴ばならないととになる．中型のスペース・ チェンバーは径 $2 \sim 3 \mathrm{~m}$ ，長さ $10 \mathrm{~m}$ としても径 $1.5 \mathrm{~m}$ 6の排気口を 30 個あけることは不可能であろう.

しかし，幸いなととに，とれらの放出ガスの大部分 は水であり，液体㗌素のトラップ，あるいはシュラウ ドで凝固してしまう。 ガスの組成が $90 \%$ 水分とすれ ば，残り $10 \%$ が油拡散ポンプの受持つぺきガス量と なりこれならば前記超大型油拡散ポンプならば3基 ですむととになるあっとす，3基といっても奏際上 はかなり大変なととであり，乙の程度以上のスペー ス・チェンバーには，むしろクライオ・ポンプをチェ ンバー内に設置したほうが有利になってくる．前記の チェンバーは内面積 $100 \mathrm{~m}^{2}$ であるから，とれを有効 
開口 $30 \%$ のクライオ・ポンプとして使えば $5 \times 10^{6} l /$ sec 程度の排気速度を有するような排気系となる。

\section{4. スペース・チェンバーの排気系}

上述のような，種々の条件の下で運転されるスペー ス・チェンバーには，それぞれ種々の能力をむった排 気系を付属させる.ここでは，一般的な排気系化つい て述べる。

4.1 ロータリー・ポンプ系 大気圧から数 Torr までの圧力で使われるスペース・チェンバーは排気系 としてロータリ一真空ポンプが用いられる. しかし， ての程度の圧力のシミュレーションは取り扱うガスの 量が非常に大きいので, 多数のロータリー・ポンプが 必要となりむしろより大きな能力をもつ他の種のポ ンプのほうが望ましい場合が多い.

4.2 スチーム・エゼクター系 ロケットの動作試 験などのように，大量のガスが発生する場合には，大 容量のポンプとしてスチーム・エゼクターが使われて いる.しかし，スチーム・エゼクターは蒸気発生源を 設けたり，水蒸気がチェンバーに逆流しないように安 全装置を必要とするなど, 種々問題が多い.

4.3 油拡散ポンプ系 初期のスペース・チェン バ一の排気系は，ほとんどが油拡散ポンプを主体とし た構成であり，大型チェンバーには 36〜 40 in などと いう超大型油搪散ポンプを 20 台以上も取り付けた例 がある．ての上うな方法で，排気速度は確保される が，油拡散ポンプからの油の逆流が非常に問題であ り, 現在では, 油拡散ポンプは一種の補助ポンプとし て使われ，他の方法，特にオイルフリ一の排気系が重 視されている。

油の逆流をなるぺく少くするために，拡散ポンプ自 体の構造にも注意せねばならないが，さらに2 段シ リーズに動作させたり，ロータリー・ポンプ油の逆流 を防ぐために，拡散ポンプとロータリー・ポンプの間 にメカニカル・ブースターを挿入する例すある。また トラップ，バッフルなどを強化するととによって油の 逆流をある程度防止できるが，とれを強化すればする ほど排気抵抗る大きくなり，総合的な排気速度が低下 するので，ある程度で妥協せねばならない，WUTZ妾 は逆流住対して十分の考慮をはらってもその量は $3 \times$ $10^{-6} \mathrm{gr} / \mathrm{min} \cdot \mathrm{cm}^{2}$ 程度むると報告しており，長期間の 電子部品のテストなどにおいては相当の㯖影響がある と GILES ( $^{5}$ が報告している.

4.4 オイル・フリーの排気系 スペース・チェン バーの排気系として，オイル・フリー之称せられるる のは, ソープション・ポンプ, スパッタ・イオン・ポ ンプ, サブリメーション・ポンプおよびクライオ・ポ

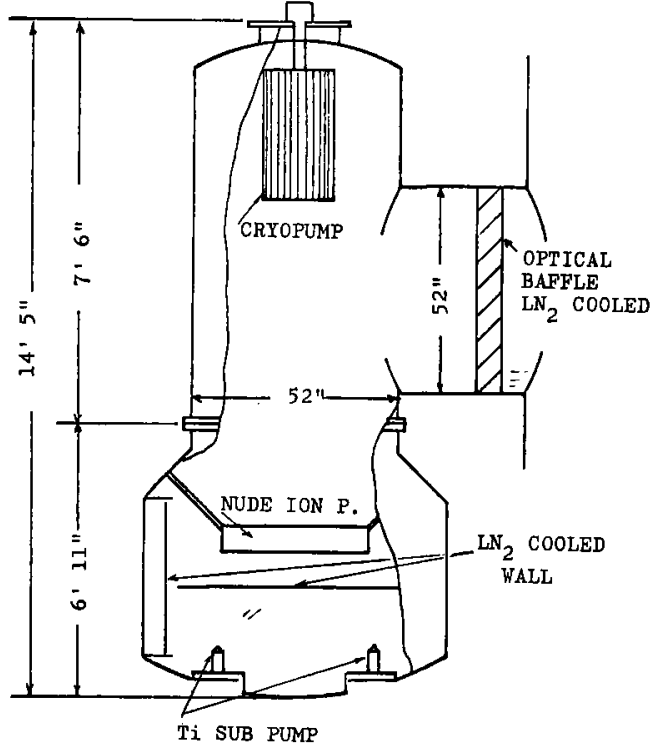

第 9 図 オイル・フリー・ポンプの組み合わせ

ンプなどがあり，機械的ポンプのターボ，モレキュ

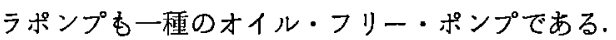

とれらのポンプはガスの瞖類によって非気速度が大 幅に異なるので，普通は数種のポンプを組み合わせて 使うことが多い。

一例として CHRISTOFFEL ${ }^{10)}$ は第 9 図のような組み 合わせの排気系を用いた，乙の場合，窒素に対する排 気速度はクライオ・ポンプが $25,000 \mathrm{l} / \mathrm{sec}$ ，チタン・ サブリメーション・ポンプは $100 \mathrm{ft}^{2}$ の液体窒素温度 の吸着面, $1 \mathrm{gr} / \mathrm{h}$ の蒸発量の条件で $250,000 \mathrm{l} / \mathrm{sec}, 1$ オン・ポンプが $500 l / \sec$ である. サブリメーション・ ポンプは水素，ヘリウム，アルゴンなどに対しては無 カであるから，イオン・ポンプによって水素，へリウ ムを排気し，クライオ・ポンプがアルゴンを担当する という役割になっており，通常のスペース・チェン バーの残留ガスの分析結果から上記の上うな組み合わ せと能力の割合が適当であるといっている.

ボーイング社の超大型チェンバーは最初油拡散ポン プとクライオ・ポンプの組み合わせの排気系を使って いたが, 最近 $200,000 \mathrm{l} / \mathrm{sec}$ のチタン・サブリメーショ ン・ポンプ, $20,000 l / \mathrm{sec}$ のクライオ・パネル， 500 $l / \mathrm{sec}$ のイオン・ポンプを 2 組拈よびチェンバー内の $15^{\circ} \mathrm{K}$ クライオ・ポンプ $2,500,000 \mathrm{l} / \mathrm{sec}$ の組み合わ甘 亿改造し，オイル・フリーで $1 \times 10^{-9}$ Torr まで排気し ている.

第 10 図は筆者らの製作した $300 l$ 小型超高真空チェ ンバーの排気特性であって，排気系は，500gr のモレ キュラ・シーブスを液体窒素温度に冷却したソープ ション・ポンプ 4 台, $400 l / \mathrm{sec}$ イオン・ポンプ, 10,000 


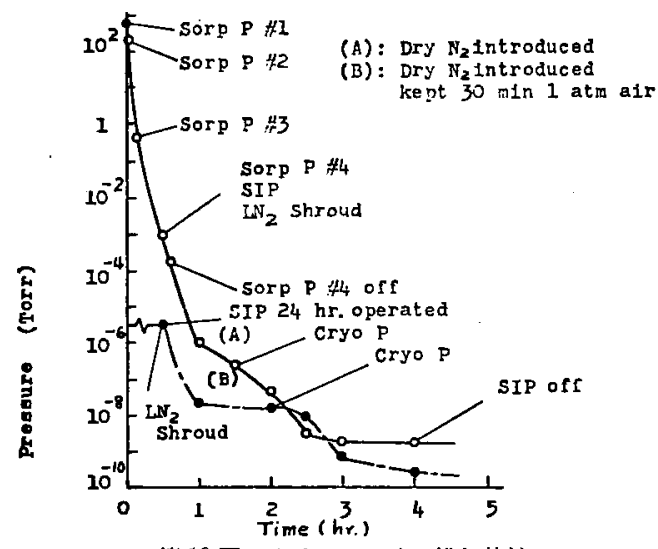

第 10 図 オイル・フリー排気特性

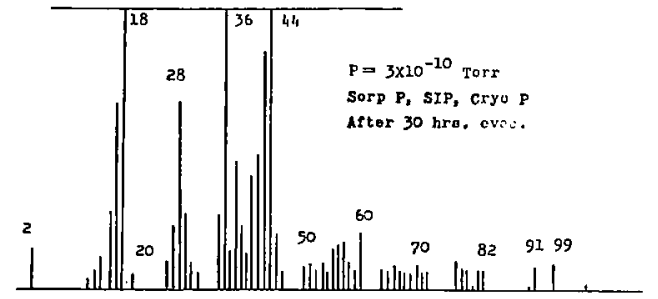

第 11 図オイル・フリー残留ガス分析

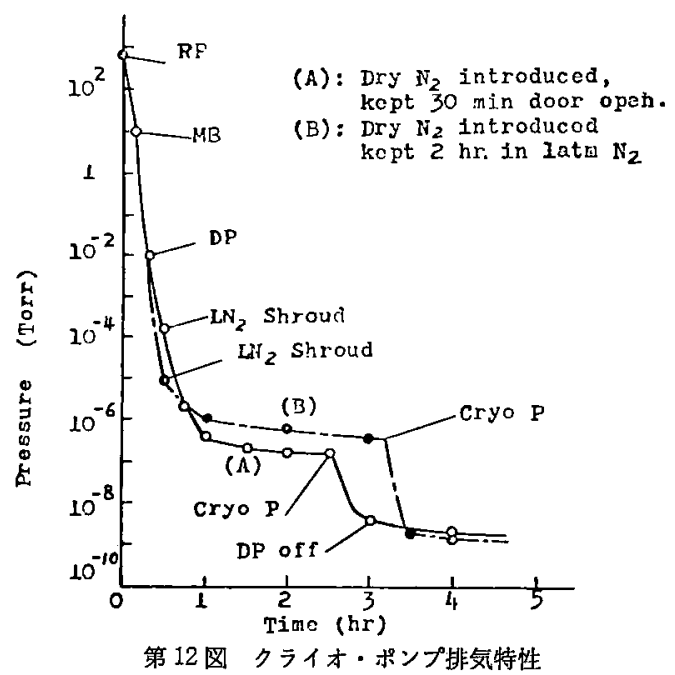

$l / \mathrm{sec}, 10^{\circ} \mathrm{K}$ クラオ・ポンプという完全なオイル フリーのポンプから成り立っている，あまりチェン バーをベークすることなく $10^{-10}$ Torr 台まで 4 時間で 排気している.

このときの残留ガスの組成をマス・フィルターで分 析した結果を第 11 図に示す。との図加らわかるよう に，チェンバーを大気にさらしてから，あまりべーク しないで超高真空まで排気した場合の残留ガスの主成 分は水，堂素，一酸化炭素であり，普通のように長時 間べークして得られた超高真空状態の残留ガスとは 塳ったようすを示す.
また第 12 図は完全なオイル・フリーではないか， $210,000 \mathrm{l} / \mathrm{sec}$ のクライオ・ポンプ, $32 \mathrm{in} 5,000 \mathrm{l} / \mathrm{sec} の$ 油拡散ポンプ, $2,000 \mathrm{~m}^{3} / \mathrm{h}$ のメカニカル・ブースター, $6,000 \mathrm{l} / \mathrm{min}$ のロータリー・ポンプからなる排気系で 径 $1.8 \mathrm{~m}$ ，長さ $5 \mathrm{~m}$ の中型スペース・チェンバーを排 気した場合の例であって，大気圧から10Torr 程度ま ではロータリー・ポンプ，それから $10^{-2}$ Torr 程度ま でをメカニカル・ブースター，それから $10^{-5}$ Torr 程 度までを油拡散ポンプ，さらに液体案素で泠却した シュラウドのポンプ作用，さらにクライオ・ポンプを 動作させて，結局 $10^{-9}$ Torr 程度まで 3 時間で排気し ている.

4.5 クライオ・ポンプ系 オイル・フリ一の排気 系に用いられるポンプの中で, クライオ・ポンプは非 常に有勃な特徵をむっている. その第 1 は，他のオイ ル・フリー・ポンプのように，いわゆる既製のポンプ として，チェンバー外部に取り付けるという使い方て はなく，チェンバー内にシュラウドと一体にして組み 込むという点である.このためクライオ・ポンプは チェンバーの設計と同時にそれぞれ種々の考虑をはら って設計され，他のポンプに比へるとその型状は数多 い種類が使われている，第 13 図は配置の一例であっ て，シュラウドはモデルに対するヒート・シンクの役 割亡同時に，クライオ・パネルの熱シールド面として の役割をむっている. 熱シールドとしては完全にクラ イオ・パネルを包み込むほうがよいが，とうすれば， 飛来するガスの分子がクライオ・パネルに到達できな くなり，その中間で妥協せねばならない，また一度， シュラウドに包まれた空間に飛来した分子は，シュラ
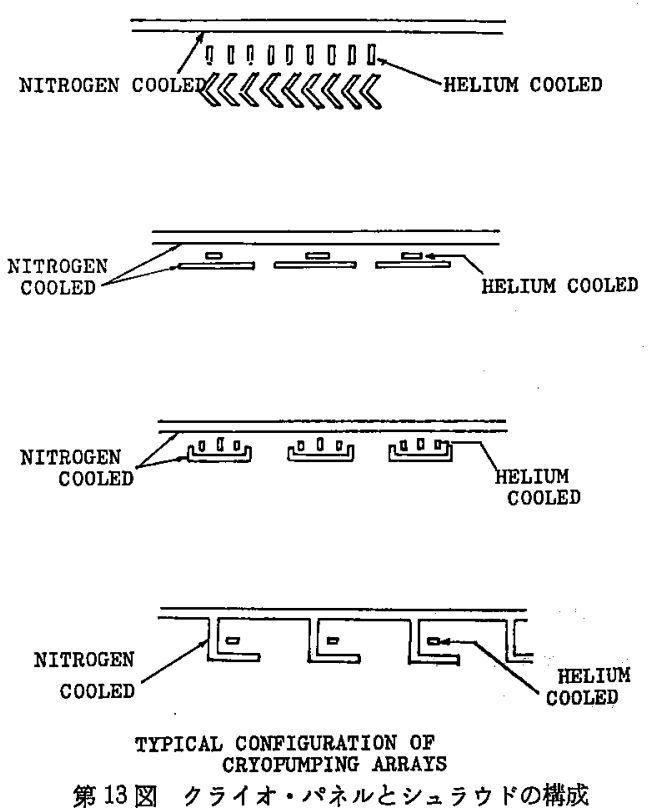

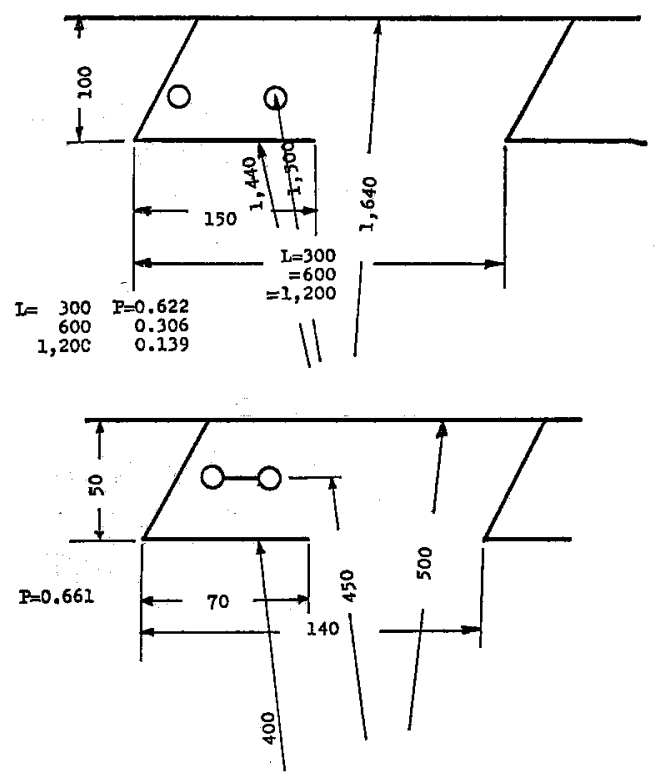

第 14 図㣫实確率 $\mathrm{P}$

ウド面で反射されて再び開口から出ていくので, 飛来 した分子がなるべくクライオ・パネルに衝突する確率 を大きくする必要がある.しかす，ての点はちょっと したシュラウドの寸法の違いで大きく異なってくる. 秋山ら ${ }^{11}$ はこの確率をモンテカルロ法で計算し, 衝突 確率として 0.2〜0.6 の範囲にあるととを求めた. 一 例として第 14 図の上うな場合はそれぞれ 0.6，0.3， 0.14 などの值が得られている.

クライオ・ポンプはチェンバー内に組み込まれるた めに，他のポンプのように限られた引き口を介して排 気するよりも遥かに大きな排気速度をすつようにな 万.

$$
\begin{array}{r}
\text { クライオ・ポンプの排気速度は自由分子の条件で } \\
\qquad S=\alpha\left(\frac{P T_{q}}{2 \pi M}\right)^{1 / 2}\left\{1-\left(\frac{T_{b}}{T_{s}}\right)^{1 / 2}\left(\frac{P_{s}}{P_{g}}\right)\right\} A \quad \text { (7) }
\end{array}
$$

で表わされる.ここに $\alpha$ は捕獲係数， $R$ はガス常数, $M$ は分子量, $A$ はクライオ・パネル面積, $T_{v}, T_{s}$ は 気相および擬縮相の温度, $P_{s}, P_{\theta}$ はそれぞれ冷却面温 度におりる飽和蒸気圧および系の全圧である．窒素に 対する $10^{\circ} \mathrm{K}$ 付近のクライオ・パネルの捕獲係数は, ほとんど1であるが，てのほかに，前述のようなシュ

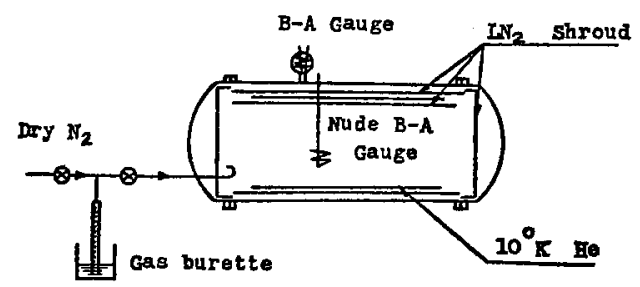

第 15 园排気䢟度の测定
ラウド入射後の捕獲係数も考える必要がある.

排気速度の測定は，第 15 図に示すように，圧力 $P$ と外部から導入する既知のガス量 $Q$ とから

$$
S=\frac{Q}{P}
$$

で求める． $Q$ の測定には別に問題はないが $P$ の測定 には後述の上うに極めてむずかしい問題があり，真空 計の種類，取り付け方法についてよく考える必要があ る.

\section{5. スペース・チェンバーの圧力測定}

一般に真空装置の圧力測定は装置内の圧力分析加完 全であっても, 取り付け位置や真空計の種類について かなりてまかい考慮をしないと正しい值が得られない てとは上く知られている，その原丙の一つは，高真空 の測定に使用する真空計はすべて圧力を絶対測定する のではなくて，圧力に侤存する種々の現象を測定して 玏換算するととにある.

高真架に执いて，最も広く使われている電離真空計 は，気体分子をイオン化し，その数を測定する真空計 であるが，チェンバー内の気体分子の密度と, 真空計 内の気体分子の密度とは明らかに差がある場合，たと えば真空計内でガス放出が起こったり，逆に真空計が ポンプ作用を示している場合についてもはたして正し いチェンバーの王力を示しているものであろうかとい う疑問がある。

真空計は一般に，絶対測定されたある圧力にある試 験容器で補正するととができる. 今, 真の圧力 $P_{c}$ の容

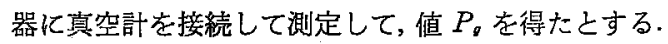
このとき，真空計内の圧力 $P_{g}$ は，たとえ $P_{c} \neq P_{0}$ で あってもさしつかえない，との真空計を他の容器に取 り付けて，同じ読み $P_{v}$ を得たとすれば。この容器の 王力 $P_{t}$ 枯正しく $P_{t}=P_{c}$ といえる. しかし，乙机は 真空計の取り付け口やその他の状熊が全く同じと考え られる場合のとき成立するてとであって, $P_{c}$ と $P_{a}$ と の関係が両者で一致しない場合は $P_{t} \neq P_{g}$ である.

さらに，電離真空計では一般に管球のほうがチェン バーより高い温度に保たれている.ての場合，もし接 続口の径があまり太くない場合はサーマル・トランス ピレーション現象が起とり，チェンバー内の分子密度 と真空計内の分子密度には温度の比の平方限に比例し た压力分布が起こる．したがって，乙の場合も真空謗卜 を較正した状態と全く同じ状態でチェンバー内の圧力 を測定すれば，同じ値を得るであろうが，口径が変 わったり，真空計の温度が变わったりした場合は温度 補正を必要とする.

スペース・チェンバー内の圧力の测定は，チェン 
バー内にシュラウドという，真空計校正時には使用し ない低温壁があるととで著しく現象が複雑になる。 シュラウド内の真の圧力 $P_{c}$, 分子密度 $n_{c}$, 気体の温 度 $T_{c}$ とし, 一方, 真空計内の王力を $P_{\theta}$, 分子密度 $n_{g}$, 気体の温度 $T_{0}$ としたとき，乙の真空計で $P_{g}^{\prime}$ と いう読みを得たよする。この真空計が上記のように室 温で，较正されたよすれば

$$
P_{g}{ }^{\prime}=P_{\mathrm{q}}=n_{g} k T_{\sigma}
$$

であるが，シュラウド内の真の圧力は

$$
P_{c}=n_{c} k T_{c}
$$

亡なる.よって

$$
\frac{P_{c}}{P_{g}^{\prime}}=\frac{n_{c} T_{c}}{n_{g} T_{q}}
$$

となる，一方，真空計の接続口における両側からの分 子の飛来頻度が等しくて平衡になっているとすれば

$$
\frac{1}{4} n_{c} v_{c}=\frac{1}{4} n_{g} v_{g}
$$

である.ここで $v_{c}, v_{0}$ はそれぞれ $T_{c}, T_{0}$ における分 子の平均運動速度である。これは温度に関して

$$
\left.\begin{array}{l}
v_{c}=\alpha \sqrt{\frac{\overline{T_{c}}}{M}} \\
v_{g}=\alpha \sqrt{\frac{\overline{T_{q}}}{M}}
\end{array}\right)
$$

の関係にあるから

$$
\frac{n_{c}}{n_{\theta}}=\frac{v_{o}}{v_{c}}=\sqrt{\frac{T_{0}}{T_{c}}}
$$

であり，てれを(11)に代入して結局

$$
\frac{P_{c}}{P_{g}^{\prime}}=\frac{T_{c}}{T_{g}} \sqrt{\frac{T_{g}}{T_{\varepsilon}}}=\sqrt{\frac{T_{c}}{T_{g}}}
$$

となり，補正が必要となる． $T_{c}=80^{\circ} \mathrm{K}, T_{0}=300^{\circ} \mathrm{K}$ とすれば $P_{g}^{\prime} \fallingdotseq(1 / 2) P_{c}$ となる.

すなわち，真空計の読みを 2 倍したあのが，チェン バーの真の圧力になる.

このように理想的な条件が常に成り立つとは限ら ず，また，ヌード真空計のように，シュラウド内に挏 入された真空棓は外部に取り付けた真空計とは全く 違った值を示す．これらの圧力の読みの評価は，クラ イオ・ポンプの排気速度の評価ばかりでなく，チェン
バー自体の能力の評洒につながる問題であるだけに, その取り扱いは慎重な考虑が必要である。

このような真空計を用いた圧力の測定より，たとえ ば液体窒素で冷却された水晶結晶の上に凝固する気体 の量によって，その発振周波数が变わることを利用し た分子入射頻度計などのほうが，スペース・チェン バーによるシミュレーション試験の本来の目的に合致 している.

\section{6. むす ひ}

スペース・チェンバーとをれに付属する排気系につ いて，その概略を紹介したが，との分野には，まだ解 決していない困難な問題が多くあり，二，三の問題に ついては，まだ定説さえ確立していないのが現状であ 万.

宇宙開発という一見はでなナショナル・プロジェク トの陰に，それを支えるための地味な努力の積み加さ わが要望されている事実を直視して，そのような発展 の一助ともなれば本稿の使命の大半ははたせたことに なると思う。

\section{文献}

1) C. G. Stergis: 507 B, National Aeronautics Meeting, New York, April 3 6, 1962.

2) D. L. Dowling, D. B. Herrick, T. A. Kellev: Trans. 8 th Vac. Symp. (1961) 1279.

3) 中山, 石并, 中川, 秦: 第 10 回真空連合講演会 (1966).

4) H. H. Соoк, H. B. Coethent : Réunion de WGLR, Munih Oct. 1963.

5) S. Giles : AIAA Space Simul. Test. Conference Nov. 1969.

6) R.L. Chuan: The Fluid Dynamics Aspect of Space Flight, Vol. 2, (1964) 41.

7) J. B. Stephens: JPL Technical Report No. 32-901.

8) J.S. Griffith: 4 th Space Simul. Conference. 69996 (1969).

9) M. Wurz: Theorie u. Praxis der Vakuumtechnik, Braunschweig (1965).

10) J. Christoffel, I. B. Loubet, A. M. Murply: 4 th Space Simul Test. Conference 69-1026 (1969).

11) 中山，秋山，斎藤：真空 14，135 (1964). 